\title{
EDUVELOP
}

Journal of English Education and Development

Volume 1, No. 2, March 2018

ISSN 2597-713X (print)

ISSN 2597-7148 (online)

\section{The Influence of Using Teams-Games-Tournament (TGT) on Simple Present Tense}

\author{
${ }^{1}$ Ahmad Munawir, ${ }^{2}$ Irmayanti, ${ }^{3}$ Ridwan \\ West Sulawesi University \\ SMK Soeparman Wonomulyo \\ West Sulawesi University \\ munawirahmad17@yahoo.com \\ irmayanti34@gmail.com \\ ridwanbody@gmail.com
}

\begin{abstract}
The objective in this research is to find out the influence of using Teams - Games - tournament (TGT) towards Simple Present tense at seventh grade of Smp Negeri 5 Wonomulyo. This is a quantitative pre-experiment research design where the researcher chose one group pre-test post-test research design. The population of this research is the students of seventh grade of SMP Negeri 5 Wonomulyo where the total number of population were 155 of five classes. The sample of population was 28 students where The researcher used technique simple purposive sampling. The result of this research proves that there is an influence of using TGT on simple present tense mastery. According to calculation, it can be seen that mean score of pretest was 56,78 and mean score of post-test was 72,5. moreover, based on the result of analysis the data, the value of t-table is 11,22 and the value of $t$-test is 1.703 , it means that $11,22>1.703$. It can be concluded that learning Simple present tense by using TGT technique has an influence towards the students simple present tense mastery of the seventh grade of SMP Negeri 5 Wonomulyo.
\end{abstract}


Key Words : Simple present tense, TGT technique

\section{Introduction}

Grammar is the rule to make sentence in English. It means that we have to study grammar to make our writing and speaking better. Handoyo (2006 :122) in the case of learners, grammatical rules enable them to know and apply how such sentence patterns should be put

together. The teaching of grammar should also ultimately center attention on the way grammatical items or sentence patterns are correctly used. In other words, teaching grammar should encompass language structure or sentences patterns, or meaning and use.

Furthermore, English grammar is very important for them specially in using simple present tense to make their language well. It uses to talk about thing in general and also we are not think only about now. Based on information obtained from the English teacher at SMP Negeri 5 Wonomulyo, it was found that many students still had difficulties in mastering grammar, especially in mastering simple present tense.

Simple present tense is important as the basic rule for the students to make and use sentence in daily life. Besides, that the students can identify and make descriptive reports and procedure text in which Simple present tense in used. Based on the interview with the English teacher, it was known that the seventh class of SMP Negeri 5 Wonomulyo from five classes are VII A, VII B, VII C, VII D and VII $E$, there are three classes of them that the lowest in using Simple Present tense.

Based on the background of the study above, the writer formulates the main research question : To what extent does Teams - Games Tournament (TGT) influence on Simple Present Tense Mastery as a case study at the seventh grade of SMP Neg. 5 Wonomulyo in academic year 2014/2015. Thus,this research is aimed to find out the influence of using TGT towards 
Simple Present Tense at the seventh grade of SMP Neg. 5 Wonomulyo in academic year 2014/2015.

\section{REVIEW OF RELATED LITERATURE \\ The concept of Simple Present tense}

Simple Present Tense according to Azar (1999) in his book Understanding and Using English Grammar : In general, the simple present tense expresses events or situations that exist always, usually, habitually; they exist now, have existed in the past, and probably will exist in the future. It is something was true in the past, is true in the present and will be true in the future and express general statement of fact and timeless truth.

According to Murphy (1994: 4) in his book entitle English Grammar in Use that Simple Present tense in talk about things in general. We are not thinking only about now. We use it to say that something happens all the time or repeatedly, or that something is true in general.

\section{The use of Simple Present Tense}

Tense is used to express events or habits repeated or habitual activity. In general, the simple present expresses events, actions and situations that are happening all the time, or exist now. For Example I take a bath twice in day. More explanation of Juwita (2008: 12) that the usages of simple present tense are as follows :

1) The present tense used to express habitual action.

2) The present tense used to express general truth.

3) The present tense used to express the skills, abilities, character owned by a person.

4) The present tense used to express quote a news, announcements, letters, books, or newspapers. In this case the verb is often used are : say, advise, warn.

5) The present tense used to express the actions that are planned to occur in the near future.

6) The present tense used to express in drama to describe the 
course of the narrative sequence and in radio or television in the shown or sporting event.

7) The present tense used to express the meaning of present continuous tense by using certain verb in simple present tense, such as believe, agree, consider, love ,expect, like, know, prefer, remember, wish, want. Etc

\section{Teams-Games-Tournament (TGT)}

\section{Technique}

TGT is one of the cooperative learning which focuses on the level of ability alone. In TGT technique uses academic game, each member was assigned to study the material in advance along with other members, and they are individually tested through the academic game. According to Shoimin (2014 : 203) TGT model cooperative learning is one type or cooperative learning model that is easy to implement, involve every student activity without any difference in status, involves the role of students as peer tutors and contains elements of the game and reinforcement.

In TGT students formed in small groups of three to five people are heterogeneous, both in academic achievement, gender, race, or ethnicity. TGT used in academic tournament, where students compete as a representative of his team against the other team members who achieve or similar achievements in the past. The components in the TGT is the presentation of the material, teams, games, tournaments, and team recognition.

\section{The Procedures of Using Teams-}

\section{Games-Tournament (TGT)}

Sdayu (2014 : 15) in his thesis.

To use TGT in teaching and learning process, follow these steps :

1. Divided the learners into groups of four or five

2. Give the learners an outline of what they will be learning and why.

3. Present new academic information to learners either verbally, in writing, or through other means such as video tape. 
4. Give the learners worksheet or other study devices to help them master academic materials. These worksheet should be guide them through the materials and show them how they can help one other learn through tutoring, quizzing one another, or team discussing.

5. Give the learners sufficient to work together to understand the ideas you have presented-several periods if necessary.

6. While the learner learning in their groups, review your records of their learning progress over the past few lessons so that you can classify each learner as low, medium, or high achiever at this time and for their aspects of their learning.

7. When it is time to check on what the learners have learned, select three at a time for the " tournament ' , the three learners should be form some category (low, medium, or high achiever), but for different group.

8. Pose a series questions (perhaps four) to the 'contestant' who will be trying to be the first to answer.

9. At the end of the round the winners earns one points for his/her team regardless of how many questions they answered correctly or how difficult the questions were.

\section{METHOD OF THE}

\section{RESEARCH}

In this research, the writer used the purposive sampling where considering the students in the class still low in grammar simple present tense. The writer chose one class of five classes of the seventh grade, where the total number of sample were 28 students.

The method of this research used quantitative research method and the writer used pre-experimental method which would be applied one group pretest posttest. the test used to test alternative hypothesis, and design presented as follow :

One Group - Pretest - Posttest Design Group Pre-test $\left(\mathrm{O}_{1}\right)$ Treatment (X) Post-test $\left(\mathrm{O}_{2}\right)$

Where:

$\mathrm{O}_{1}=$ Pre-test 


$$
\begin{array}{ll}
\mathrm{X} & =\text { Treatment } \\
\mathrm{O}_{2} & =\text { Post-test }
\end{array}
$$

This design involved one group which was pre-test $\left(\mathrm{O}_{1}\right)$, exposed to a treatment $(\mathrm{X})$ and post-test $\left(\mathrm{O}_{2}\right)$. In the pre-test $\left(\mathrm{O}_{1}\right)$, the writer gave simple present tense as test to all students. In the treatment $(\mathrm{X})$, the writer gave in four meetings and for each meeting the students were guided to simple present tense material by using TGT technique.

Then, in post-test $\left(\mathrm{O}_{2}\right)$ the writer gave Post-test to the students; the pre-test and post-test were the same, just given at different times. The purposed of the post-test was to know whether the students' simple present tense mastery develop or not after giving the treatment.

The instrument of this research, the writer used test. The test consist of pre-test about simple present tense consist of Nominal and verbal. The student would be asked to translate the sentence into English in form simple present tense. The test was used in pre-test and post-test. Pre-test was intended to find the students' prior knowledge before the learning process in the treatment and post-test was conducted to find out the students' grammar skill after conducting of learning process. The writer would give written test about English grammar to the students, and it would be used to measure the students' English grammar skill in simple present tense. The test consists of 20 items multiple choice questions.

\section{Technique of Data Analysis}

The data from pre-test and posttest was analyzed in inferential statistics using test. The steps taken were listed as follows:

1. The writer would collect the students' paper after the students have answered the questions.

2. Grouping the right answer of the students.

3. Grouping the wrong answer of the students.

4. Classifying the rating score of students into the following converted score:
a. Scoring the students correct answer : 
Score

\section{Students correct answer the number of students}

$$
\text { x } 100 \%
$$

Concerning the formulated above, it explains is all the correct answer of each students are divided by the total number of students. Then, we times $100 \%$ to get score of the students.

b. Classifying based on the following criteria :

Table 1. the scoring classification

\begin{tabular}{|r|c|c|}
\hline & Classifying & Score \\
\hline 1 & Very Good & $86-100$ \\
\hline 2 & Good & $70-85$ \\
\hline 3 & Fair & $56-69$ \\
\hline 5 & Poor & $36-55$ \\
\hline
\end{tabular}

(Depdiknas in Anita's thesis , 2012:43)

5. Compute the average percent of the students' score in comprehending the English grammar skill as follows:

a. To find out the frequency distribution of scores of students' ability in grammar, the researcher would apply the following formula:

$$
\mathrm{X}=\frac{\sum f x}{N}
$$

Where:
$\mathrm{X}=$ Mean score

$f \quad=\quad$ The frequency with which the score occurs $x=$ Score of students $\sum f x=$ The total or the sum of students' score frequency

$N=$ The number of the testes / The number of students

Jabu (2005:116-117) Based on formula above, it explained that to get mean score $(\mathrm{X})$ is the total 
frequency of the students' score ( $\sum f x$ ) divided by the totsl number of Students $(N)$.

b. To find out the standard deviation of test relating to students' ability in English grammar, the writer would apply the following formula:

$s . d=\sqrt{\frac{\sum d^{2}}{N}}$

Where:

s.d = Standard deviation

$d^{2}=$ Square of students' score

$\sum d^{2}=$ The total or the sum of square students' score $N \quad=$ The number of the testes / The number of students

Jabu (2005:117-118)

Based on formula above, the explanation was to get standard deviation (s.d) the square root $(\sqrt{ })$ of the total score of $\mathrm{d}^{2}\left(\sum \mathrm{d}^{2}\right)$ divided by the total score of students or sample $(\mathrm{N})$. c. To find out the differences between the score of pre-test and the post-test by using the formula as follows:

$\mathrm{t}$

$$
=\frac{\mathrm{D}}{\sqrt{\frac{\sum \mathrm{D}^{2}-!}{\mathrm{N}(\mathrm{N}-}}} \text { ice: }=\frac{\sum \mathrm{I}}{\mathrm{N}}
$$

Where:

$\mathrm{t}=$ test of significant $\bar{D} \quad=$ the mean of the differences score $\sum \mathrm{D}=$ the sum of the difference $\mathrm{D}^{2}=$ the difference of the mean score $\mathrm{N}=$ total number of sample

Sukardi (2003:91-92)

\section{FINDING AND DISCUSSION}

\section{Findings}

1. Pre- test Analysis

a. Table 2. The frequency and percentage of the result of the students' pretest score. 


\begin{tabular}{|c|c|c|c|c|}
\hline \multirow[b]{2}{*}{$\begin{array}{l}\mathbf{N} \\
\mathbf{0}\end{array}$} & \multirow[b]{2}{*}{$\begin{array}{c}\text { Inte } \\
\text { rval } \\
\text { scor } \\
\text { e }\end{array}$} & \multirow[b]{2}{*}{$\begin{array}{l}\text { Classif } \\
\text { ication }\end{array}$} & \multicolumn{2}{|c|}{ Pretest } \\
\hline & & & $\begin{array}{c}\text { Freq } \\
\text { uenc } \\
\mathbf{y}\end{array}$ & $\begin{array}{c}\text { Perce } \\
\text { ntage } \\
(\%)\end{array}$ \\
\hline 1 & $86-$ & Very & 0 & 0 \\
\hline . & 100 & good & 1 & 3.6 \\
\hline 2 & $70-$ & Good & 14 & 50 \\
\hline • & 85 & Fair & 13 & 46,4 \\
\hline 3 & $\begin{array}{c}56- \\
69\end{array}$ & $\begin{array}{l}\text { Poor } \\
\text { Very }\end{array}$ & 0 & 0 \\
\hline 4 & $\begin{array}{c}36- \\
55 \\
0- \\
35\end{array}$ & poor & & \\
\hline & & & 28 & $\begin{array}{c}100 \\
\%\end{array}$ \\
\hline
\end{tabular}

Depdiknas, in Anita's thesis, 2012:14

Table 2 above indicates that $0(\%)$ student in Very good classification, 1 student $(3,6 \%)$ in good, 14 students $(50 \%)$ in fair, 13 students $(46,4 \%)$ in poor and none of them got very poor. Table 1 means that the students mastery in grammar still low before using TGT technique to understand Simple Present Tense.

Furthermore, after finding frequency and percentage students' pre-test result, the writer researched the mean score. The following table and formula as follows :

Table 3 .The frequency distribution of pretest

\begin{tabular}{|c|c|c|c|}
\hline NO. & $\begin{array}{c}\text { Score } \\
(\boldsymbol{x})\end{array}$ & $\begin{array}{c}\text { Score } \\
(\boldsymbol{f})\end{array}$ & $\begin{array}{c}\text { Score } \\
(\boldsymbol{f} \boldsymbol{x})\end{array}$ \\
\hline 1. & 70 & 1 & 70 \\
2. & 65 & 7 & 455 \\
3. & 60 & 7 & 420 \\
4. & 55 & 5 & 275 \\
5. & 50 & 4 & 200 \\
6. & 45 & 2 & 90 \\
7. & 40 & 2 & 80 \\
\hline Total & \multicolumn{3}{|c}{$\begin{array}{c}\sum f x= \\
\end{array}$} \\
\hline
\end{tabular}

Based on the table 3 above, it shows that the first column indicates the score of pre-test $\left(\mathrm{X}_{1}\right)$, the second column is frequency of the students $(f)$ and the last column indicates the total frequency of the students' score $(f x)$, from the descriptions, explained that there are $1(f)$ student get score 
70 , so 70 times 1 , get frequency of students' score $(f x)$ is $70,7(f)$ students get score $65\left(\mathrm{X}_{1}\right)$, so $(f x)$ is 455, $7(f)$ students get score 60 , so $(f x)$ is 60 times 7 is $420,5(f x)$ students get score 55 so 55 times 5 is 276, $4(f)$ students get score 50 so 50 times 4 is 200, $2(f)$ students get score 45 so 45 times 2 is 90 and $2(f)$ students get score 40 , so 40 times 2 is 80 .

From the explanation above, the total frequency of students' score in Pretest $\sum f x=1.590$, so the result of $\sum f x$ divided by the total score of students $(\mathrm{N})$ is 28 . We can see of the following formula below :

The formula of mean score

$$
\begin{aligned}
& X=\frac{\sum f x}{N}=\frac{1.590}{28}=56,78 \\
& X=56,78
\end{aligned}
$$

Based on the result above, it shows that the total of the sum of students' score frequency were 1.590 points and the number of the students were 28. To find out of the mean score is the total of the sum of students' score frequency divided to the number of students equal to 56,78 points. The result of mean score was 56,78 points.

\section{Standard deviation of pretest}

The pre-test score of standard deviation was analyzed in the following table.

Table 4. Standard deviation of pre-test

\begin{tabular}{|c|c|c|c|c|}
\hline No & $\begin{array}{c}\text { The number } \\
\text { of Students }\end{array}$ & $\mathbf{X}$ & $\mathbf{D}$ & $\mathbf{D}^{\mathbf{2}}$ \\
\hline 1 & student 1 & 70 & 13,22 & 174,7684 \\
\hline 2 & student 2 & 65 & 8,22 & 67,5684 \\
\hline 3 & student 3 & 65 & 8,22 & 67,5684 \\
\hline 4 & student 4 & 65 & 8,22 & 67,5684 \\
\hline 5 & student 5 & 65 & 8,22 & 67,5684 \\
\hline 6 & student 6 & 65 & 8,22 & 67,5684 \\
\hline 7 & student 7 & 65 & 8,22 & 67,5684 \\
\hline 8 & student 8 & 65 & 8,22 & 67,5684 \\
\hline 9 & student 9 & 60 & 3,22 & 10,3684 \\
\hline
\end{tabular}




\begin{tabular}{|c|c|c|c|c|}
\hline 10 & student 10 & 60 & 3,22 & 10,3684 \\
\hline 11 & student 11 & 60 & 3,22 & 10,3684 \\
\hline 12 & student 12 & 60 & 3,22 & 10,3684 \\
\hline 13 & student 13 & 60 & 3,22 & 10,3684 \\
\hline 14 & student 14 & 60 & 3,22 & 10,3684 \\
\hline 15 & student 15 & 60 & 3,22 & 10,3684 \\
\hline 16 & student 16 & 55 & 3,22 & 3,1684 \\
\hline 17 & student 17 & 55 & $-1,78$ & 3,1684 \\
\hline 18 & student 18 & 55 & $-1,78$ & 3,1684 \\
\hline 19 & student 19 & 55 & $-1,78$ & 3,1684 \\
\hline 20 & student 20 & 55 & $-1,78$ & 3,1684 \\
\hline 21 & student 21 & 50 & $-1,78$ & 45,9684 \\
\hline 22 & student 22 & 50 & $-6,78$ & 45,9684 \\
\hline 23 & student 23 & 50 & $-6,78$ & 45,9684 \\
\hline 24 & student 24 & 50 & $-6,78$ & 45,9684 \\
\hline 25 & student 25 & 45 & $-6,78$ & 138,7684 \\
\hline 26 & student 26 & 45 & $-11,78$ & 138,7684 \\
\hline 27 & student 27 & 40 & $-11,78$ & 281,5684 \\
\hline 28 & student 28 & 40 & $-16,78$ & 281,5684 \\
\hline & Total & 1.590 & 0 & $\sum d^{2}=1.806,6836$ \\
\hline
\end{tabular}

Table 4 above shows that the total score of students' pre-test result was 1.590 points and the total of square students' score was $1.806,6836$ points and still the total number of students were 28 students. To get the number of standard deviation, it was used the formula below:

$$
\begin{aligned}
& \text { s. } d=\sqrt{\frac{\sum d^{2}}{N}}=\sqrt{\frac{1.806,6836}{28}}=\sqrt{64,5} \\
& \text { s. } d=8,03
\end{aligned}
$$

Based on result of the formula above, it shows the total score of students' pre-test result was (1.590) points and the total of square students' score was $(1.806,6836)$ points. Then, the root of the total of 
square students' score (1.590) divided the total number of students (28) equal to $(8,03)$ points. Therefore, the score of standard deviation in pre-test was $(8,03)$

2. Post-test analyses

a. Table 5. The frequency and percentage of the result of the students' posttest score.

\begin{tabular}{|c|c|c|c|c|}
\hline \multirow[b]{2}{*}{$\begin{array}{l}\mathbf{N} \\
\mathbf{0}\end{array}$} & \multirow[b]{2}{*}{$\begin{array}{c}\text { Inte } \\
\text { rval } \\
\text { scor } \\
\text { e }\end{array}$} & \multirow[b]{2}{*}{$\begin{array}{l}\text { Classif } \\
\text { ication }\end{array}$} & \multicolumn{2}{|c|}{ Post-test } \\
\hline & & & $\begin{array}{c}\text { Freq } \\
\text { uenc } \\
\mathbf{y}\end{array}$ & $\begin{array}{c}\text { Perce } \\
\text { ntage } \\
(\%)\end{array}$ \\
\hline 1 & $\begin{array}{c}86- \\
100\end{array}$ & $\begin{array}{l}\text { Very } \\
\text { good }\end{array}$ & $\begin{array}{c}2 \\
15\end{array}$ & $\begin{array}{c}7,1 \\
53,6\end{array}$ \\
\hline 2 & $\begin{array}{c}70- \\
85\end{array}$ & $\begin{array}{l}\text { Good } \\
\text { Fair }\end{array}$ & $\begin{array}{c}11 \\
0\end{array}$ & $\begin{array}{c}39,3 \\
0\end{array}$ \\
\hline 3 & $\begin{array}{c}56- \\
69\end{array}$ & $\begin{array}{l}\text { Poor } \\
\text { Very }\end{array}$ & 0 & 0 \\
\hline 5 & $\begin{array}{c}36- \\
55 \\
0- \\
35\end{array}$ & poor & & \\
\hline & & & 28 & $\begin{array}{c}100 \\
\%\end{array}$ \\
\hline
\end{tabular}

Vol. 1 No. 2 March 2018 points and it could be stated as representative of mean score in pretest because it was lower then the result of mean score in pre-tes

Table 5 above shows that after giving the students treatment, 2 students $(7,1 \%)$ in very good classification, 15 students $(53,6 \%)$ in Good, 11 students $(39,3 \%)$ in Fair and none of them in Poor and In very Poor Classification. This table means that there is difference between students' score in pretest and students' score in post test. Furthermore, after finding frequency and percentage students' posttest result, the writer researched the mean score. The following table and formula as follows :

b. Table 6 The frequency distribution of post-test

\begin{tabular}{|c|c|c|c|}
\hline NO. & $\begin{array}{c}\text { Score } \\
(\boldsymbol{x})\end{array}$ & $\begin{array}{c}\text { Score } \\
(\boldsymbol{f})\end{array}$ & $\begin{array}{c}\text { Score } \\
(\boldsymbol{f} \boldsymbol{x})\end{array}$ \\
\hline 1. & 90 & 2 & 180 \\
2. & 85 & 4 & 340 \\
3. & 80 & 5 & 400 \\
4. & 75 & 2 & 150 \\
\hline
\end{tabular}




\begin{tabular}{|c|c|c|c|}
\hline 5. & 70 & 4 & 280 \\
6. & 65 & 4 & 260 \\
7. & 60 & 7 & 420 \\
\hline Total & & 28 & 2.030 \\
\hline
\end{tabular}

Based on the table 6 above, it shows that the first column indicates the score of pre-test $\left(\mathrm{X}_{1}\right)$, the second column is frequency of the students $(f)$ and the last column indicates the total frequency of the students' score $(f x)$, from the descriptions, explained that there are $2(f)$ student get score 90 , so 90 times 2 , get frequency of students' score $(f x)$ is $180,4(f)$ students get score 85 so $(f x)$ is 340 , $5(f)$ students get score 80 , so $(f x)$ is 80 times 5 is $400,2(f)$ students get score 75 so 75 times 2 is $150,4(f)$ students get score 70 so 70 times 4 is 280, $4(f)$ students get score 65 so 65 times 4 is 260 and $7(f)$ students get score 65 , so 65 times 7 is 420 .

From the explanation above, the total frequency of students' score in Pre-test $\sum f x=2.030$, so the result of $\sum f x$ divided by the total score of students $(\mathrm{N})$ is 28 . We can see of the following formula below :

$$
\begin{aligned}
& \text { c. The formula of the mean } \\
& \text { score } \\
& X=\frac{\sum f x}{N}=\frac{2.030}{28}=72,5
\end{aligned}
$$

Based on result of the formula above, it shows the total or the sum of students' score frequency were (2.030) points and the number of students were (28) students. To find out the mean score, The total or the sum of students' score frequency (2.030) divided the number of students $(28)$ equal to $(72,5)$ points. Therefore the mean score of posttest was (72,5)points.

\section{d. Table 7 Standard}

Deviation of Posttest

\begin{tabular}{|c|c|c|c|c|}
\hline No & $\begin{array}{c}\text { The Number } \\
\text { of Student }\end{array}$ & $\mathbf{X}$ & $\mathbf{D}$ & $\mathbf{D}^{\mathbf{2}}$ \\
\hline 1 & student 1 & 90 & 17,5 & 306,25 \\
\hline 2 & student 2 & 90 & 17,5 & 306,25 \\
\hline 3 & student 3 & 85 & 12,5 & 156,25 \\
\hline 4 & student 4 & 85 & 12,5 & 156,25 \\
\hline 5 & student 5 & 85 & 12,5 & 156,25 \\
\hline
\end{tabular}




\begin{tabular}{|c|c|c|c|c|}
\hline 6 & student 6 & 85 & 12,5 & 156,25 \\
\hline 7 & student 7 & 80 & 7,5 & 56,25 \\
\hline 8 & student 8 & 80 & 7,5 & 56,25 \\
\hline 9 & student 9 & 80 & 7,5 & 56,25 \\
\hline 10 & student 10 & 80 & 7,5 & 56,25 \\
\hline 11 & student 11 & 80 & 7,5 & 56,25 \\
\hline 12 & student 12 & 75 & 2,5 & 6,25 \\
\hline 13 & student 13 & 75 & 2,5 & 6,25 \\
\hline 14 & student 14 & 70 & $-2,5$ & 6,25 \\
\hline 15 & student 15 & 70 & $-2,5$ & 6,25 \\
\hline 16 & student 16 & 70 & $-2,5$ & 6,25 \\
\hline 17 & student 17 & 70 & $-2,5$ & 6,25 \\
\hline 18 & student 18 & 65 & $-7,5$ & 56,25 \\
\hline 19 & student 19 & 65 & $-7,5$ & 56,25 \\
\hline 20 & student 20 & 65 & $-7,5$ & 56,25 \\
\hline 21 & student 21 & 65 & $-7,5$ & 56,25 \\
\hline 22 & student 22 & 60 & $-12,5$ & 156,25 \\
\hline 23 & student 23 & 60 & $-12,5$ & 156,25 \\
\hline 24 & student 24 & 60 & $-12,5$ & 156,25 \\
\hline 25 & student 25 & 60 & $-12,5$ & 156,25 \\
\hline 26 & student 26 & 60 & $-12,5$ & 156,25 \\
\hline 27 & student 27 & 60 & $-12,5$ & 156,25 \\
\hline 28 & student 28 & 60 & $-12,5$ & 156,25 \\
\hline & Total & 2.030 & 0 & $\sum d^{2}=2880,87$ \\
\hline
\end{tabular}

Table 7 above shows about the score of standard deviation in post-test. From the total score of students' pretest result was (2.030) points and the total of square students' score was

Vol. 1 No. 2 March 2018
$(2.880,87)$ points and still the total number of students were (28) students. To get the number of standard deviation, it was used the formula below: 

$s . d=\sqrt{\frac{\sum d^{2}}{N}}=\sqrt{\frac{2.880,87}{28}}=\begin{aligned} & (28) \text { equal to }(10,14) \text { points. } \\ & \text { Therefore, the score of standard }\end{aligned}$
s. $d=10,14$
deviation in post-test was $(10,14)$
Based on result of the formula above, it shows the total score of students' post-test result was (2.030) points and it could be stated as representative of mean score in post- test. The result of formula above indicated that the score of posttest was higher than pre-test score.

points and the total of square students' score was $(2.880,87)$

points. Then, the root of the total of square students' score (2.030)

Table 8 The mean score and standard deviation of The students Pretest and Posttest.

divided the total number of students

\begin{tabular}{|c|c|c|}
\hline Type of Test & Mean & S.d \\
\hline Pre-test $\left(\mathrm{X}_{1}\right)$ & 56,78 & 8.03 \\
Post-test $\left(\mathrm{X}_{2}\right)$ & 72,5 & 10,14 \\
\hline
\end{tabular}

Table 8 above indicates that the mean score of pretest was $(56,78)$ and the result of mean score of posttest was $(72,5)$. The standard deviation of students' pretest was $(8,03)$ and standard deviation of students' posttest was $(10,14)$. It was proved by the mean score of posttest was higher than the mean score of pretest. It means that after giving treatment to students by using Teams - Games - Tournament technique the students' simple present tense mastery was increased.

Interpretation of $\mathrm{T}$-value and $\mathrm{T}$ table Data

Table 8 The result of T-test

\begin{tabular}{|l|l|l|l|l|l|}
\hline No & Students & $\mathrm{X}_{1}$ & $\mathrm{X}_{2}$ & $\mathrm{D}$ & $\mathrm{D}^{2}$ \\
\hline
\end{tabular}




\begin{tabular}{|c|c|c|c|c|c|}
\hline 1 & Student 1 & 70 & 90 & 20 & 400 \\
\hline 2 & student 2 & 65 & 80 & 15 & 225 \\
\hline 3 & Student 3 & 65 & 70 & 5 & 25 \\
\hline 4 & Student 4 & 65 & 85 & 20 & 400 \\
\hline 5 & Student 5 & 65 & 75 & 10 & 100 \\
\hline 6 & Student 6 & 65 & 85 & 20 & 400 \\
\hline 7 & Student 7 & 65 & 80 & 15 & 225 \\
\hline 8 & Student 8 & 65 & 80 & 15 & 225 \\
\hline 9 & Student 9 & 60 & 65 & 5 & 25 \\
\hline 10 & Student 10 & 60 & 70 & 10 & 100 \\
\hline 11 & Student 11 & 60 & 75 & 15 & 225 \\
\hline 12 & Student 12 & 60 & 90 & 30 & 900 \\
\hline 13 & Student 13 & 60 & 80 & 20 & 400 \\
\hline 14 & Student 14 & 60 & 85 & 25 & 625 \\
\hline 15 & Student 15 & 60 & 70 & 10 & 100 \\
\hline 16 & Student 16 & 55 & 60 & 5 & 25 \\
\hline 17 & Student 17 & 55 & 85 & 30 & 900 \\
\hline 18 & Student 18 & 55 & 60 & 5 & 25 \\
\hline 19 & Student 19 & 55 & 65 & 10 & 100 \\
\hline 20 & Student 20 & 55 & 80 & 25 & 625 \\
\hline 21 & Student 21 & 50 & 60 & 10 & 100 \\
\hline 22 & Student 22 & 50 & 70 & 20 & 400 \\
\hline 23 & Student 23 & 50 & 60 & 10 & 100 \\
\hline 24 & Student 24 & 50 & 60 & 10 & 100 \\
\hline 25 & Student 25 & 45 & 60 & 15 & 225 \\
\hline 26 & Student 26 & 45 & 65 & 20 & 400 \\
\hline 27 & Student 27 & 40 & 60 & 20 & 400 \\
\hline 28 & Student 28 & 40 & 65 & 25 & 625 \\
\hline \multicolumn{2}{|l|}{ Total } & 1.590 & 2.030 & $\sum \mathrm{D}=440$ & $\sum D^{2}=8.400$ \\
\hline
\end{tabular}


$\mathrm{D}=\frac{\sum \mathrm{D}}{\mathrm{N}}=\frac{440}{28}=15,71$

$$
\begin{aligned}
t & =\frac{\mathrm{D}}{\sqrt{\frac{\sum \mathrm{D}^{2}-\frac{\left(\sum \mathrm{D}\right)^{2}}{\mathrm{~N}}}{\mathrm{~N}(\mathrm{~N}-1)}}}=\frac{15,71}{\sqrt{\frac{8400-\frac{(440)^{2}}{28}}{28(28-1)}}} \\
& =\frac{15,71}{1,4}
\end{aligned}
$$$$
\mathrm{t}=11,22
$$

Table 8 shows that the result of significant test was $(11,22)$ points from the difference of mean score was $(15,71)$ points. So, it can be concluded that there is an influence on the result of students' pre-test and

post-test. To find out the degree of freedom (df), the writer used the following formula:

the degree freedom is :

$$
\begin{aligned}
& (\mathrm{df})=\mathrm{n}-1 \quad(\mathrm{df})=28-1 \quad(\mathrm{df})=27 \\
& \mathrm{t}_{\text {table }}(0,05 ; 27) \quad=1,703 \\
& \mathrm{t}_{\text {value }}>\mathrm{t}_{\text {table }} \quad=11,22>1,703
\end{aligned}
$$

Concerning the calculated score of degree of freedom (df) above, the significant different of t-test value and t-table were elaborated in the following table.

\begin{tabular}{|c|c|c|}
\hline $\begin{array}{c}\text { Vari } \\
\text { able }\end{array}$ & $\begin{array}{c}\text { t-test } \\
\text { value }\end{array}$ & t-table \\
\hline \hline
\end{tabular}

$$
\begin{gathered}
=\frac{15,71}{\sqrt{\frac{8400-6914,28}{756}}}=\frac{15,71}{\sqrt{1,96}} \\
\mid \begin{array}{c|c|c|}
X_{1^{-}} & 11,22 & 1,703 \\
X_{2} & & \\
\hline
\end{array}
\end{gathered}
$$

The calculation above shows that t-test value is higher than t-table value. It means that the null hypothesis $\left(\begin{array}{ll}\mathrm{H} & 0\end{array}\right)$ is rejected and alternative hypothesis $\left(\mathrm{H}_{1}\right)$ is accepted. So, it could be concluded that use of TGT technique can influence the students on simple present tense mastery of the seventh grade of SMP Negeri 5 Wonomulyo.

\section{Discussions}

Based on findings that presented on result of the data analysis on the test, it shows that the students simple present tense mastery before using TGT technique was poor where the most of them got unexpected score. The mean score was (56.78) which was classified as 
fair classification. After learning Simple Present Tense by using TGT technique was good clasification where most of them got expected score. The mean score was (72.5), which classified as good classification.

Based on result of standard deviation score, the differences between the standard deviation of pretest and posttest where the students score in pretest lower than the students score in posttest. The minimum score in pretest is (40) points and the maximum score is (70) points. However, the minimum score in posttest is (60) points and the maximum score is (90) points.

The ability of the students' simple present tense mastery score when did pre-test was low because almost the students had difficulties in using simple present tense in test that was given. They still confused to differentiate usage of simple present tense. Furthermore, based on the students' problem ability in simple present tense mastery which occurred in pre-test, the researcher conducted treatment for four meetings with different topic each meeting.

After giving treatment the students' simple present tense mastery improved, it shown that the post-test score. The students were no more confused about the usage of simple present tense, they had been able to differentiate the usage of simple present tense. It was proved the use of Teams-GamesTournament (TGT) gave influence of students' simple present tense mastery.

Based on the result of the t-test value, it shows that $\mathrm{t}$-table value was lower than t-test value where the value of the t-test was $(11,22)$ and the value of the t-table was (1.703). The data shows that the null hypothesis was rejected and alternative hypothesis was accepted. It can be concluded that learning Simple present tense by using TGT technique can influence the students simple present tense mastery of the seventh grade of SMP Negeri 5 Wonomulyo.

The researcher of this research took sixth meeting in collecting the 
data. First, the researcher gave pretest to the students about simple present tense test that consist 20 items multiple choice questions. The time of allocation was $2 \times 30$ minutes in the pre-test and post-test, while $2 \times 40$ minutes each treatment. The second until the fifth meeting were treatments, and the last meeting the researcher gave post-test.

In the process, the first treatment and the second treatment, the researcher gave the same material about Nominal but different contents and worksheet. Then, he third treatment and the forth treatment the researcher gave the same material about verbal with different contents and worksheet.

The researcher used marker to write on the whiteboard and prepared questions made of paper that consist the questions for tournament. First, the researcher gave explanation about simple present tense and gave the procedure about the TGT technique, then the students were divided into group consist 4 or 5 people in group.
Second, the researcher gave worksheet each students in team related to the material which have been explained. The students did their worksheet by him/herself in team. Thus, if one member of the group has not understood, then the task of yet others of members who already understand the need to help his / her friend to be able to understand the material. Furthermore, after all groups have finished the worksheet the students were asked to forward the shirt tournament. all students in the group following the tournament. This activity repeated each treatment. But, each group is replaced every treatment according to the value of tournament students.

On the last time, the researcher gave post-test to the students to know their simple present tense mastery. The instrument of the posttest same with the pre-test before that consist 20 items of multiple choice questions. The allocation was 60 minutes.

\section{CONCLUSION}


Looking at the data analysis, the researcher would like to put the following conclusion. Firstly, the ability of the students of SMP Negeri 5 at seventh grade in mastering simple present tense before using TGT technique was fair classification where the mean score was 56,78. After learning simple present tense by using TGT technique was good clasification where the mean score was 72,5. Secondly, the t-test value was higher than t-table value $=11,22>1.703$. At last in this research the alternative hypothesis was accepted. It means that the use of TGT technique influence the students' simple present tense mastery at the seventh grade of SMP Negeri 5 Wonomulyo Kab. Polewali Mandar.

\section{REFERENCES}

Anita. 2012. The Use of Talking Stick Technique in Stimulating Speaking Ability of The Second Grade Students in SMA Negeri 2 Majene. Thesis. Makassar. FBS UNM
Azar, Betty Schrampfer. 1989. Understanding and Using English Grammar.

Third Edition. United State of America : Longman

Huda, Miftahul. 2011. Cooperative Learning. Yogyakarta : PUSTAKA PELAJAR

Jabu, Baso. 2005. English language Testing.Makassar: Badan Penerbit UNM.

Juwita, Anne. 2009. 160 Menit Menguasai 16 Tenses. Jakarta : Hi-fest.

Maryani, R. 2011. Teaching Simple Present Tense Trough Students Teams Achievement Division, at the senenth year of Pelita Harapan Junior High School South Jakarta.Skripsi. Paper Unpublished Tarbiyah Faculty Jakarta: UIN

Murphy, Raymond. 1994. English Grammar in Use. New York : Cambridge university Press. Sugiyono. 2011 . Metode Penelitian Kombinasi (Mixed Method) . Yogyakarta: ALFABETA, cv 
Sukardi. 2003. Metodologi

Penelitian Pendidikan

"Kompetensi dan

Praktiknya”. Yogyakarta:

Bumi Aksara.

Sdayu, Agung. 2014. The Effectiveness of Using Teams Games Tournament (TGT) in Teaching Reading of Narrative Text at SMPN 1Pakuhaji.Paper Unpublished Tarbiya Faculty Jakarta: UIN

Shoimin, Aris. 2014. 68 Model Pembelajaran inovatif dalam Kurikulum 2013. Yogyakarta : AR-RUZZ MEDIA

Widodo, Hamdoyo Puji. 2006 . Approaches and Procedures for teaching Grammar. The English Program Politeknik Negeri Jember. Jawa Timur 